\title{
DATING THE NEOLITHIC: METHODOLOGICAL PREMISES AND ABSOLUTE CHRONOLOGY
}

\author{
Johannes Müller \\ Institut für Ur- und Frühgeschichte, University of Kiel, Germany. Email: johannes.mueller@ufg.uni-kiel.de.
}

\begin{abstract}
Ideas of Neolithic societies and of the identities of Neolithic individuals changed rapidly during the last decade. The archaeological concept of "culture" implies sequential changes of material culture in spatial and temporal "slices." The term "society" describes human behavior within social identities, which could produce huge differences in material culture. Ideas of Neolithic "cultures" are no longer valid, as absolute chronological evidence points to overlapping phenomena of material culture and social developments. A combined use of correspondence analysis (to detect similarities and differences in material culture) and radiocarbon data (to identify the chronological character of material culture) exemplifies such an approach in the deconstruction and reconstruction of Neolithic central Germany.
\end{abstract}

\section{INTRODUCTION}

One important aim of prehistoric archaeology is the reconstruction of prehistoric societies. The task is related both to the classification and combination of the remaining material culture of such societies as well as to the concept of social organization and social theory concerning illiterate societies. While the archaeological concept of "culture" implies sequential changes of material culture in spatial and temporal "slices," the term "society" describes human behavior within social identities, which could produce huge differences in material culture (for discussion see Tilley 1990, 1996; Wotzka 2000; Müller-Scheessel and Burmeister 2006). Both concepts stand for differences in the rethinking of social relations. While the former describes clear patterns of directed changes through history in a more or less evolutionary sense, the latter favors possibilities of a multidirectional development. Thus, we must talk about processes when defining societies.

The chronological differentiation of typologically classified and categorized items forms the basic information about contemporary or non-contemporary appearance of social expressions, visible in material culture. Thus, the procedures and boundaries of dating methods limit or enable the applicability of the outlined concepts. In the past, especially in European areas with huge densities of archaeological features and artifacts, "cultural" approaches dominated archaeological enquiries. Scientific dating was either used if the results supported the appearance or disappearance of e.g. ceramic styles in a sequential order or rejected if a fuzzy chronological pattern would have to be postulated. For example, in central European archaeology only a few case studies are known in which typological classifications and dating were clearly differentiated (e.g. Furholt 2003; Raetzel-Fabian and Furholt 2006). The resolution of dating methods therefore influences the form in which societies are reconstructed by archaeologists.

In this paper, the archaeology of Neolithic central Europe is chosen to highlight the consequences of typological classification of ceramic styles and radiocarbon dating for the reconstruction of Neolithic societies.

\section{METHOD}

During the Neolithic, the Mittelelbe-Saale region formed one of the highest populated European regions, with many social differences visible within the archaeological remains (Figure 1). Between 4100 and $2800 \mathrm{cal} \mathrm{BC}, 1145$ excavated sites with 711 closed assemblages in $\sim 15,000 \mathrm{~km}^{3}$ have been recorded (Müller 2001). The earliest central European burial mounds, megalithic monuments, and causewayed enclosures as well as nicely decorated ceramics, prestige axes, and early copper objects 


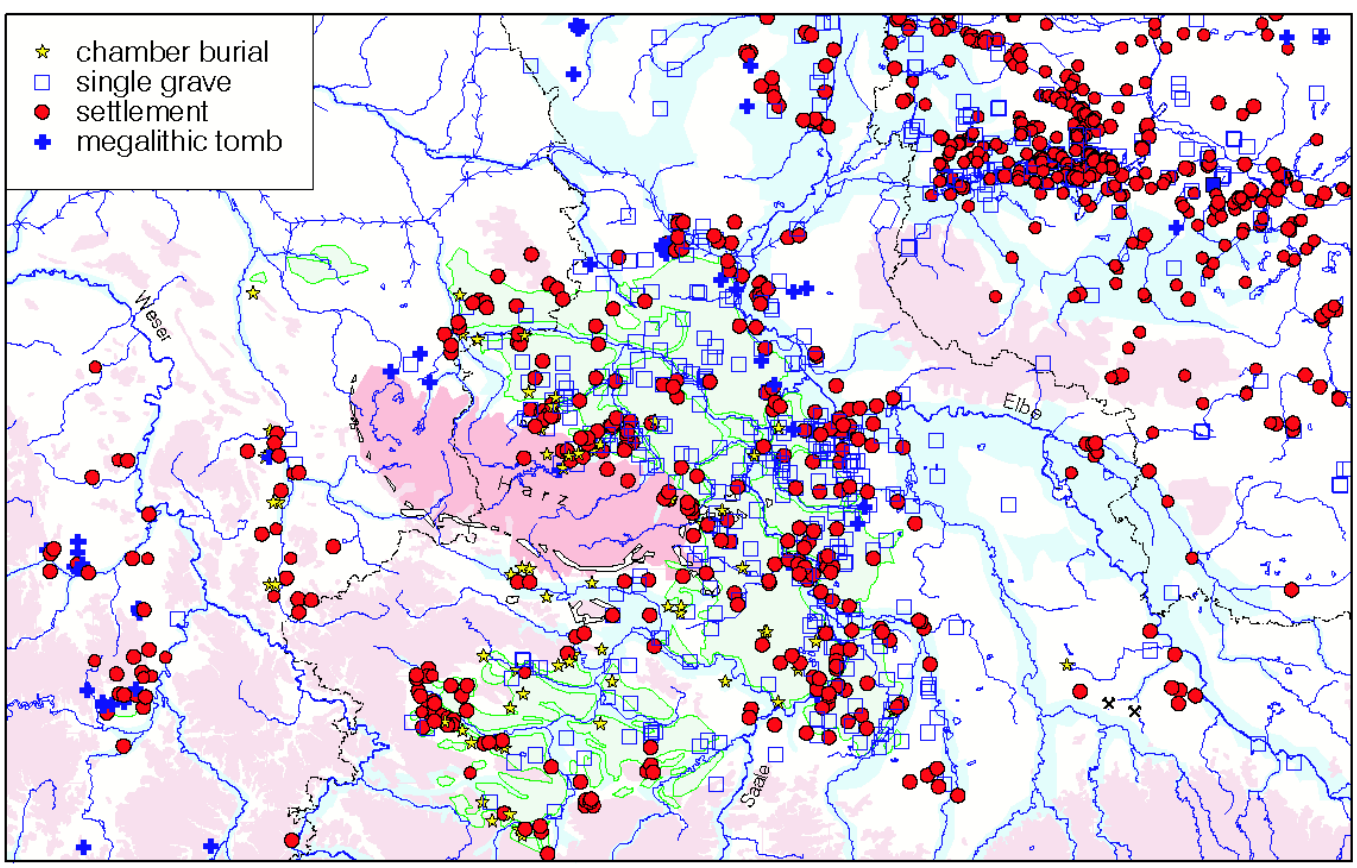

Figure 1 The distribution of Young and Late Neolithic sites in the Mittelelbe-Saale region. The high population density is characteristic for central Germany 4100-2800 cal BC.

attracted many researchers to evaluate the development of the Neolithic period in that region. Most of the archaeologists reconstructed "cultures" as spatially and temporally limited units that followed one after the other (e.g. Beran 2000a; compare to a different region, Hafner and Suter 1997). Not only typochronological but also settlement studies tried to describe linear regional developments, which were influenced by material or human input from other regions.

These approaches were deconstructed by the help of statistical classification methods and ${ }^{14} \mathrm{C}$ dating in the course of different dating projects (Müller 2000; Czebreszuk and Müller 2001; Müller and van Willigen 2001). For instance, the categorization of decoration patterns into clearly defined ornament classes, motives, and variations enabled us to conduct analyses in which the typological distance between closed assemblages could be expressed on a normalized scale. As a result, the overlapping of (per definition) clear-cut "cultures" and "groups" became obvious and the limitation of intuitive classification patterns, which were treated as paradigms by former researchers, visible. In addition to other methods of statistical classifications, the explorative use of correspondence analysis finally decoded the relatedness of assemblages. ${ }^{14} \mathrm{C}$ data were used to verify the chronological or non-chronological significance of the similarity gradients, and with this, the chronological or social meaning of the described elements of material culture. As a result, the combined application of correspondence analysis (CA) (Greenacre 2007) and ${ }^{14} \mathrm{C}$ dating became a powerful tool for the verification of typochronological units and the reconstruction of prehistoric - in this case, Neolithic - identities (Müller 2001:58ff.). The outline of the methodological approach is as follows (see Figure 2):

- The independence of different subanalyses is a basic necessity for later synthesis. Similarity analyses, spatial patterning, relative dating, and absolute dating were conducted independently from each other. As a result, the final chronological interpretation and the possibility of a social interpretation are reached by merging all evidence. 
- 711 closed finds, 55 stratigraphies, 213 contact finds (mixed finds), and $117{ }^{14} \mathrm{C}$ dates formed the database of the enquiry.

- Correspondence and spatial analyses were used to detect groups of similarities in material culture ("assemblage groupings").

- Scientific dating methods (in this case, ${ }^{14} \mathrm{C}$ ) and vertical stratigraphies were used as tools for the evaluation of successions, and mixed assemblage records for the detection of contemporary existence.

- The combination of the results from assemblage groupings and dating procedures resulted in chronological groups and periods. A priori not only periods of huge similarities in material culture but also periods of combined dissimilar assemblages are possible.

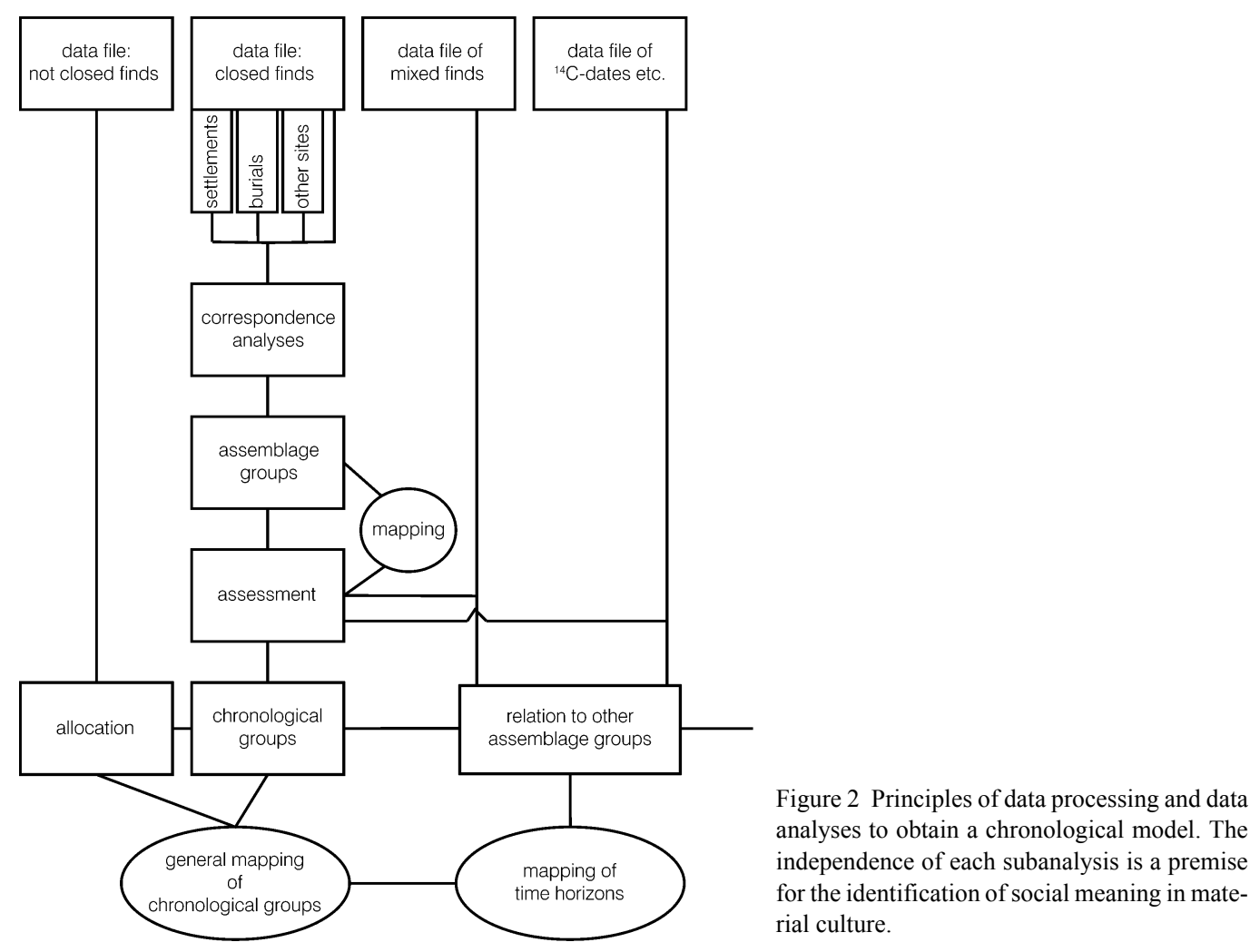

All accelerator mass spectrometry (AMS) data used in this approach were carefully selected with respect to at least 2 premises:

1. The ${ }^{14} \mathrm{C}$ data are taken from short-lived materials; thus, human or animal bones, grains, or charcoal of short-lived species were taken for dating. Older samples, measured on long-lived material like bulk charcoal samples including old wood, were excluded from the analyses. Actually, most of the dating was done on human bones.

2. The contemporaneity of date and the archaeological context is assured as best as possible: In the case of single burials, the dating of human bones ensure the closest relation between the moment of deposition of the skeleton $\left({ }^{14} \mathrm{C}\right.$ dated) and of the grave goods. In the case of domestic features, the dating of short-lived samples of pits or house floors ensure a relative contem- 
poraneity of about $\pm 50 \mathrm{yr}$, depending on the reconstruction of depositional processes. Thus, the representativeness of the data is assured, as the link of the samples with the archaeological assemblage is guaranteed both for burials as well as for domestic and ritual pits.

The ${ }^{14} \mathrm{C}$ data discussed here are all done on human or animal bone samples.

\section{RESULTS AND DISCUSSION}

Different subanalyses were used to deal with characteristic ceramic assemblages of different stages of Neolithic central Germany. For the sake of simplicity, 3 examples are chosen to explain and describe the procedures and the results.

\section{Example 1}

\section{Baalberge-Ceramic Without Chronological Significance}

The chronology of burials with Baalberge ceramics (about 3800-3300 cal BC) has been a subject of discussion during the last $40 \mathrm{yr}$. Several authors (e.g. Lichardus 1976) postulated 2 different chronological phases and associated them with economic and social changes (introduction of metallurgy, first burial mounds for single individuals in central European prehistory). ${ }^{14} \mathrm{C}$ dating proved that typological differences had no or only a limited chronological significance (Müller 2001:63ff.). In contrast, sex/gender differences obviously influenced material culture and led to different stylistic variation of burial pots (Figure 3).

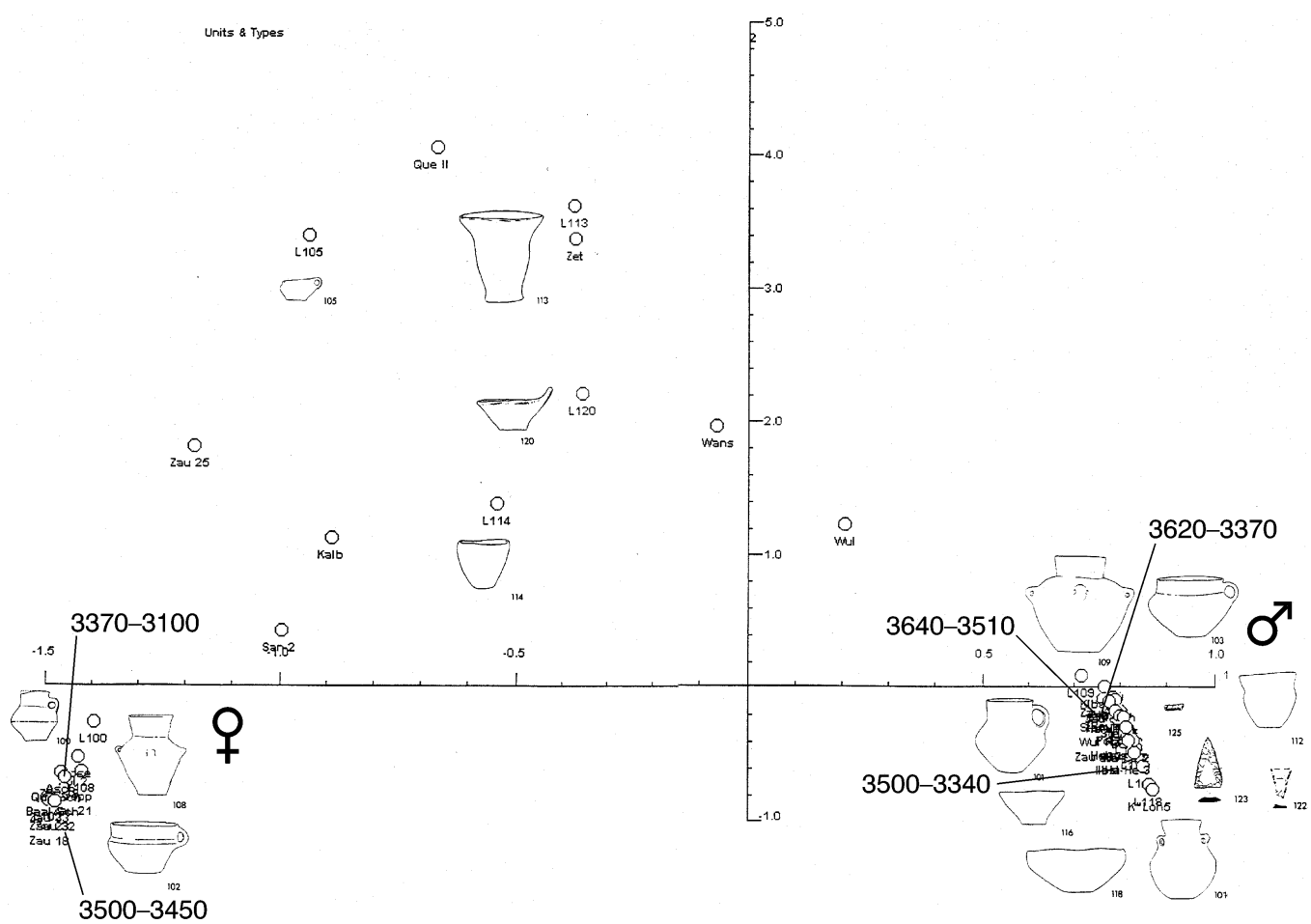

Figure 3 Correspondence analysis of Baalberge burials. Two assemblage groupings are visible, which do not relate to chronology (compare ${ }^{14} \mathrm{C}$ dates) but to sex/gender. In addition to the ${ }^{14} \mathrm{C}$ dates of assemblages, which could be used in the $\mathrm{CA}$, further ${ }^{14} \mathrm{C}$ dates for the 2 typological groupings are listed in Appendix 1. 


\section{Example 2}

\section{Salzmünde-Chronological Sequence of a Ceramic Style}

Typochronological analyses, which did not use ${ }^{14} \mathrm{C}$ dates, positioned Salzmünde ceramics in a sequential order in between Baalberge (Younger Neolithic) and Walternienburg (Late Neolithic). Different authors postulated that the duration of this style was no longer than $200 \mathrm{yr}$ (e.g. Beran 2000b). In correspondence analyses (CA), all closed assemblages with a Salzmünde ceramic type were integrated into the record (Figure 4). While a gradient of similarity is visible in the CA, in most Salzmünde closed finds, types of other "archaeological groups" appear. A separation of different assemblage groupings is possible (Müller 2001:96ff.). As ${ }^{14} \mathrm{C}$ dates (Appendix 2) correspond to the gradient of the $\mathrm{CA}$, the chronological relevance of the style development is proved. The stylistic development lasted over a time span of several centuries (3700-2700 cal BC), not just $200 \mathrm{yr}$ as others have argued. Knowing the general chronological trend of the ceramic assemblages by single ${ }^{14} \mathrm{C}$ dates of individual Salzmünde assemblages as well as sum calibrations of stylistic similarity groups, the author applied a sequence calibration using OxCal 4.0. (compare Bayliss et al. 2007).

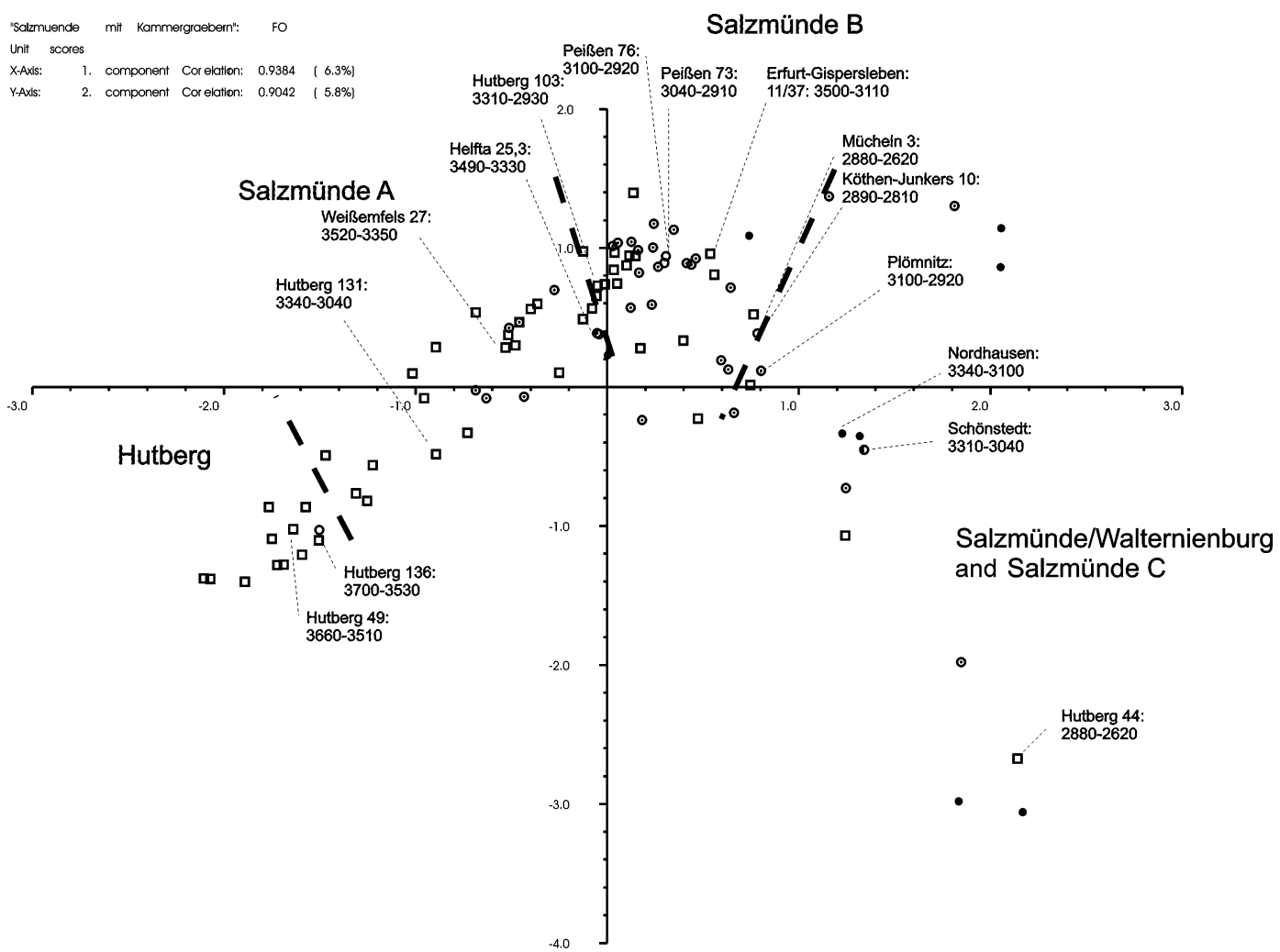

Figure 4 Correspondence analysis of Salzmünde sites. Displayed are ${ }^{14} \mathrm{C}$ dates and assemblage groupings. ${ }^{14} \mathrm{C}$ dates prove the chronological connotation of the CA results and the long-lasting period of the Salzmünde ceramic style. The ${ }^{14} \mathrm{C}$ dates are listed in Appendix 2.

For this purpose, the data were grouped according to the observed assemblage groupings. In model A, a chronological overlap of the assemblage groups is allowed, while in model B a successive sequence is assumed. This method delivers good indices of agreement whether the phases are modeled as overlapping or successive. 
The results are summarized in Figures 5 and 6-7 display both models. In result, a closer examination of subphases of the stylistic development was possible. In contrast to the Baalberge example the combined application of $\mathrm{CA}$ and ${ }^{14} \mathrm{C}$ analyses resulted in a sequential chronological order of a stylistic development.

\begin{tabular}{|c|c|c|c|}
\hline & & Overlapping & Successive \\
\hline & & cal BC $68 \%$ & cal BC $68 \%$ \\
\hline $\begin{array}{l}\text { Start } \\
\text { sequence }\end{array}$ & & $3831 \mathrm{BC}(68.2 \%) 3579 \mathrm{BC}$ & \\
\hline \multirow[t]{3}{*}{ Hutberg } & start & $\begin{array}{l}3689 \mathrm{BC}(27.2 \%) 3630 \mathrm{BC} \\
3620 \mathrm{BC}(41.0 \%) 3543 \mathrm{BC}\end{array}$ & $\begin{array}{l}3707 \mathrm{BC}(36.7 \%) 3614 \mathrm{BC} \\
3605 \mathrm{BC}(31.5 \%) 3541 \mathrm{BC}\end{array}$ \\
\hline & duration & $0(68.2 \%) 170$ years & $0(68.2 \%) 174$ years \\
\hline & end & $\begin{array}{l}3645 \mathrm{BC}(9.2 \%) 3608 \mathrm{BC} \\
3603 \mathrm{BC}(59.0 \%) 3459 \mathrm{BC}\end{array}$ & $3556 \mathrm{BC}(68.2 \%) 3478 \mathrm{BC}$ \\
\hline \multirow[t]{3}{*}{$\begin{array}{l}\text { Salzmünde } \\
\text { A }\end{array}$} & start & $3570 \mathrm{BC}(68.2 \%) 3431 \mathrm{BC}$ & $3556 \mathrm{BC}(68.2 \%) 3478 \mathrm{BC}$ \\
\hline & duration & $0(68.2 \%) 175$ years & $8(68.2 \%) 123$ \\
\hline & end & $3467 \mathrm{BC}(68.2 \%) 3329 \mathrm{BC}$ & $3464 \mathrm{BC}(68.2 \%) 3390 \mathrm{BC}$ \\
\hline \multirow{3}{*}{$\begin{array}{l}\text { Salzmünde } \\
\text { B }\end{array}$} & start & $3531 \mathrm{BC}(68.2 \%) 3386 \mathrm{BC}$ & $3464 \mathrm{BC}(68.2 \%) 3390 \mathrm{BC}$ \\
\hline & duration & $398(68.2 \%) 670$ years & $469(68.2 \%) 603$ years \\
\hline & end & $3045 \mathrm{BC}(68.2 \%) 2869 \mathrm{BC}$ & $2967 \mathrm{BC}\left(68.2^{\circ}\right) 2857 \mathrm{~B}$ \\
\hline \multirow[t]{3}{*}{$\begin{array}{l}\text { Salzmin̈nde } \\
\mathrm{C}\end{array}$} & start & $2998 \mathrm{BC}(95.4 \%) 2705 \mathrm{BC}$ & $2967 \mathrm{BC}\left(68.2^{\circ} \%\right) 2857 \mathrm{~B}$ \\
\hline & duration & $0(68.2 \%) 128$ years & $\begin{array}{l}0(2.7 \%) 16 \\
35(2.9 \%) 46 \\
52(62.6 \%) 286 \text { years } \\
\end{array}$ \\
\hline & end & $\begin{array}{l}2863 \mathrm{BC}(13.7 \%) 2831 \mathrm{BC} \\
2805 \mathrm{BC}(54.5 \%) 2693 \mathrm{BC}\end{array}$ & $\begin{array}{l}2868 \mathrm{BC}(7.2 \%) 2845 \mathrm{BC} \\
2813 \mathrm{BC}(0.7 \%) 2810 \mathrm{BC} \\
2804 \mathrm{BC}(58.1 \%) 2658 \mathrm{BC} \\
2652 \mathrm{BC}(2.2 \%) 2643 \mathrm{BC}\end{array}$ \\
\hline $\begin{array}{l}\text { End } \\
\text { sequence }\end{array}$ & & $2806 \mathrm{BC}(68.2 \%) 2556 \mathrm{BC}$ & \\
\hline $\mathrm{A}_{\text {model }}$ & & $99.8 \%$ & $111.4 \%$ \\
\hline$\overline{\mathrm{A}_{\text {overall }}}$ & & $99.3 \%$ & $112.2 \%$ \\
\hline
\end{tabular}

Figure 5 Results of the sequential calibration of Salzmünde with OxCal 4.0. The phases are modeled as overlapping or successive (compare Figures 6-7).

As a style, Salzmünde stands only for a single decoration style in a wider range of stylistic variations, which could prove to be contemporary with the detected Salzmünde development. A combined approach of CA and ${ }^{14} \mathrm{C}$ was applied to a database, which joined all assemblages of the mentioned styles (Baalberge, Salzmünde, Walternienburg, and Bernburg). As a result, a spatially different development was displayed on the 1. Eigenvector, while the 2. Eigenvector showed the chronological development of the interlinked style types (Müller 2001:176ff.). The general chronology (Hutberg, 3625-3525 cal BC; Salzmünde A, 3525-3400 cal BC; Salzmünde B, 3400-2900 cal BC; Salzmünde C, 2900-2750 cal BC) allows the description of general social changes within these centuries. The exact chronological position of each assemblage depends on the quantitative 
proportion of ceramic types within the assemblage, which is responsible for its position in the absolute-dated CA sequence.

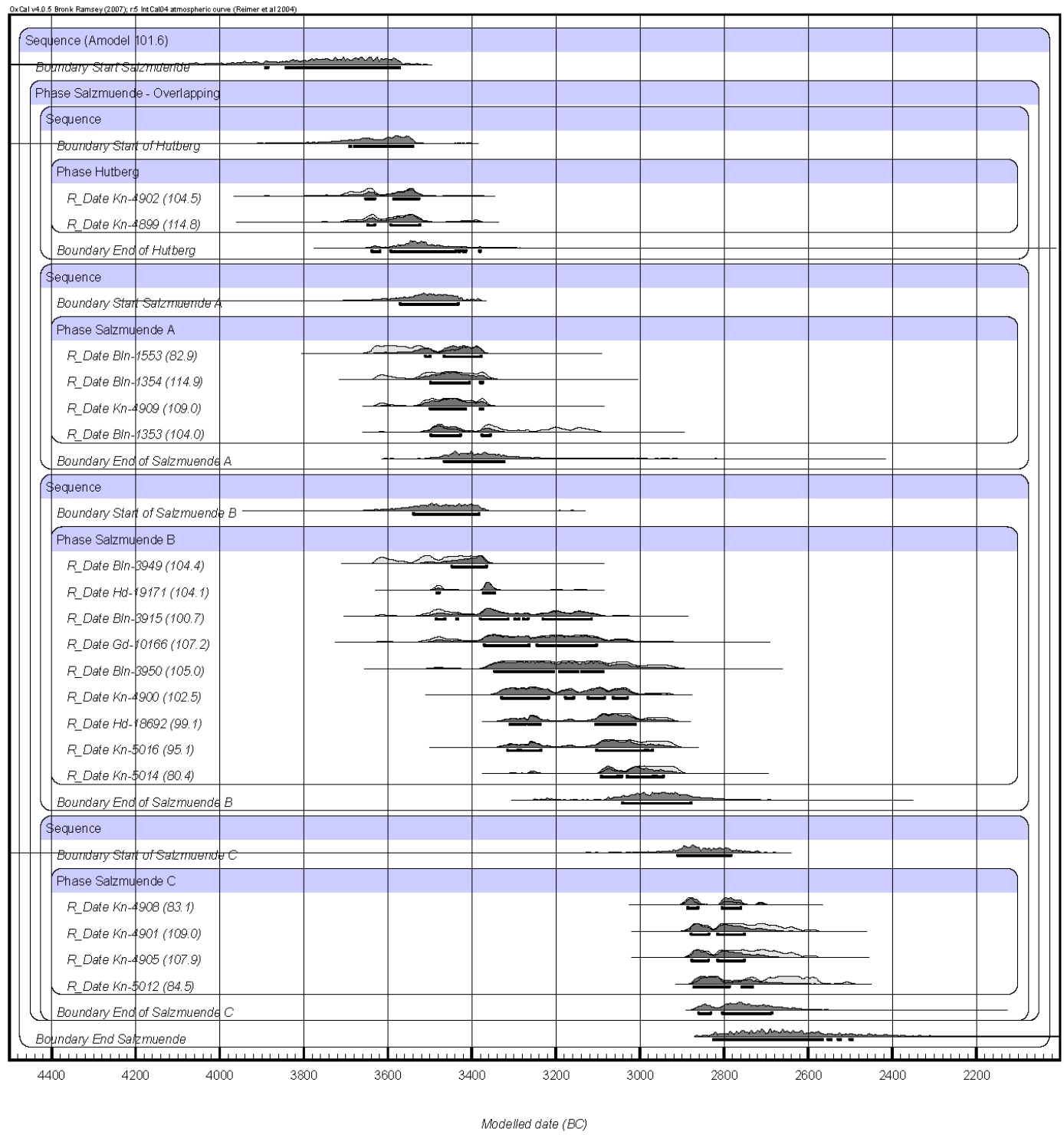

Figure 6 Calibration of Salzmünde assemblages (model A). The phases are modeled as independent, and overlapping is allowed. The ${ }^{14} \mathrm{C}$ dates are listed in Appendix 2.

\section{Example 3}

\section{Globular Amphorae-Ritual and Domestic Differences}

Some of the ceramic styles of the central German Neolithic showed significant differences during contextual analyses: e.g. decoration patterns of Globular Amphorae (GA) ceramics were used quite differently both in their chronological and their semiotic use in domestic and ritual spheres of the societies around $2900 \mathrm{cal} \mathrm{BC}$ (Müller 1996, 2001:192ff.). This is the result of a twofold approach. 


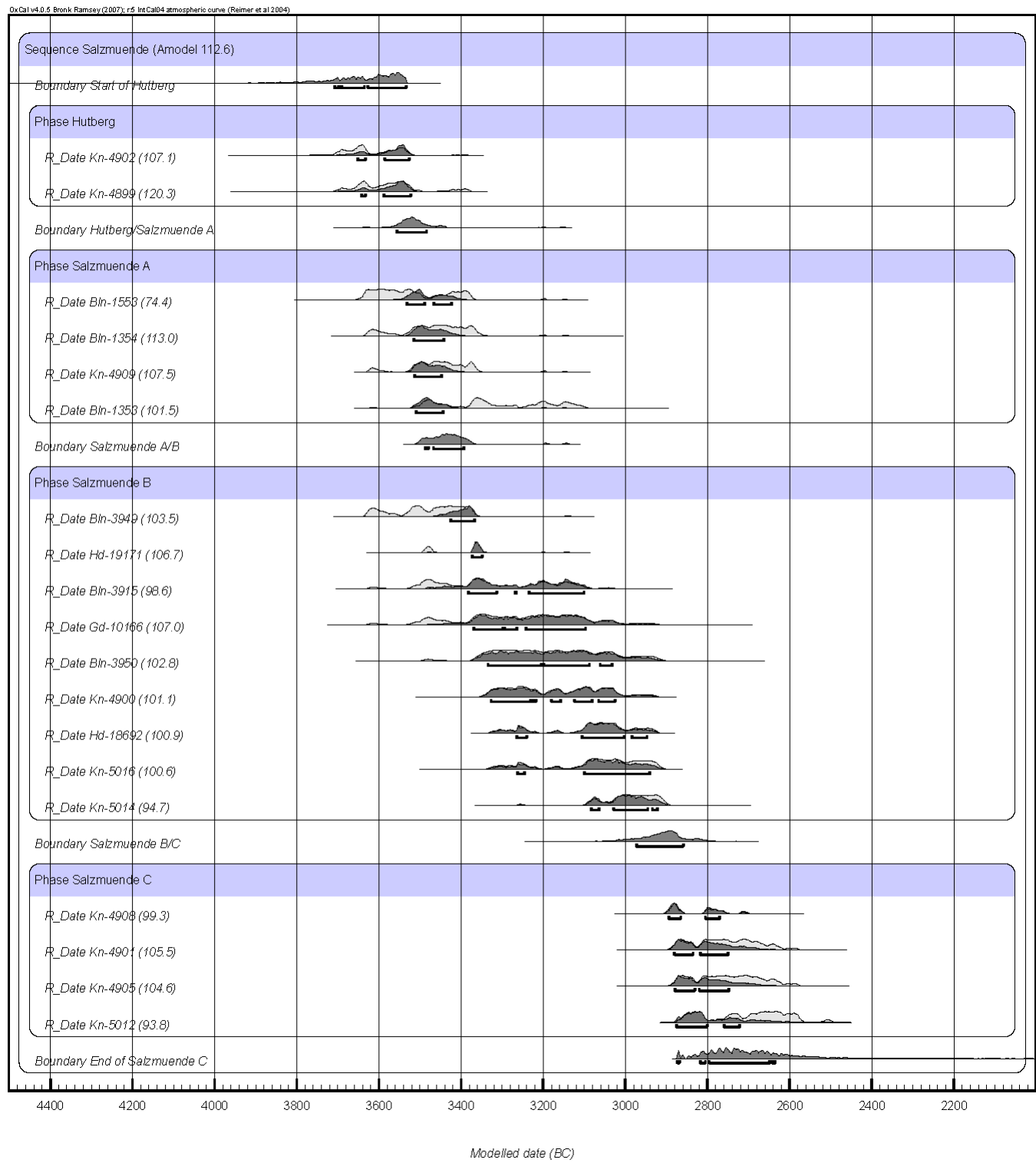

Figure 7 Sequence calibration of Salzmünde assemblages (model B). The developmental assemblage groups are placed in a sequence. The phases are modeled as successive. ${ }^{14} \mathrm{C}$ dates are listed within Appendix 2.

First of all, several correspondence analyses were conducted for burials, domestic sites, and the whole GA record (Figure 8). In spite of the small number of ${ }^{14} \mathrm{C}$ data, different techniques to use ${ }^{14} \mathrm{C}$ data for the reconstruction of chronological sequences (including sequential calibration) proved the chronological relevance of the statistical gradient of the CA for burials and the CA for domestic sites. The differences in both sequences as well as the contemporary straits of the 2 stylistic developments are explainable only by a changing ornament system in different spheres of the society (domestic versus ritual). Furthermore, differences in the first appearance of identical decoration types in burials and domestic sites were proven (Figure 9). Thus, sequential absolute dating com- 
bined with CA made it possible to detect the flow of decoration patterns, which probably means semiotic systems between the ritual and the domestic sphere of a Neolithic society.

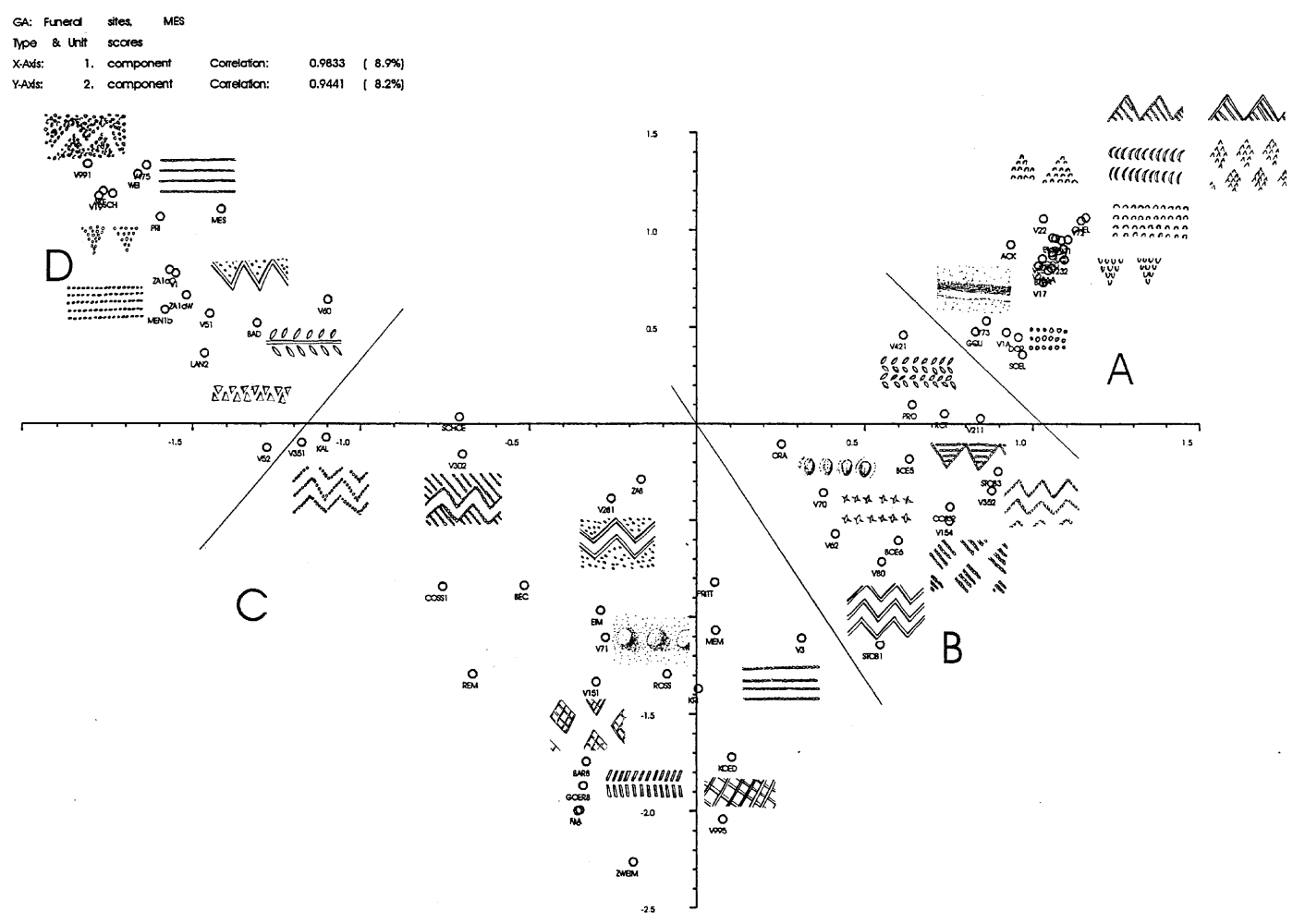

Figure 8 Globular Amphorae ceramics. Correspondence analysis of decoration patterns on burial pots. Four assemblage groupings and their chronological development are visible and proved by ${ }^{14} \mathrm{C}$ dates.

\section{Central German Neolithic: Multicultural Approach}

Besides the described examples, other $\mathrm{CA}$ and ${ }^{14} \mathrm{C}$ analyses resulted in the detection of 22 different assemblage groups, which existed between 4100-2800 cal BC in central Germany (Müller 2001: 248ff.). The overlapping of many absolute results is due to the use of different styles at the same time (Figure 10). The variability of ${ }^{14} \mathrm{C}$ dates due to variation in the calibration curve was excluded as the main reason for the construction of the contemporaneity of some ceramic styles, because mixed finds of different styles and vertical stratigraphies support the model that was derived by CA and ${ }^{14} \mathrm{C}$. Bearing in mind the introductory remarks, the concept of monolithic archaeological cultures should be rejected in favor of the multicultural dimension of the archaeological record. Obviously, the chronological model can be used to describe developments of technological, economic, or demographic matters as well as to reconstruct the ideological background of these societies, which enhanced the multistylistic use and integration of style systems into Neolithic social life.

In this respect, we could establish the following:

- the interwoven spatial distributions of ceramic styles existed around 2900 cal BC (Figure 11), reflecting the use of different sign systems in different social spheres by local communities and regional "identities"; 


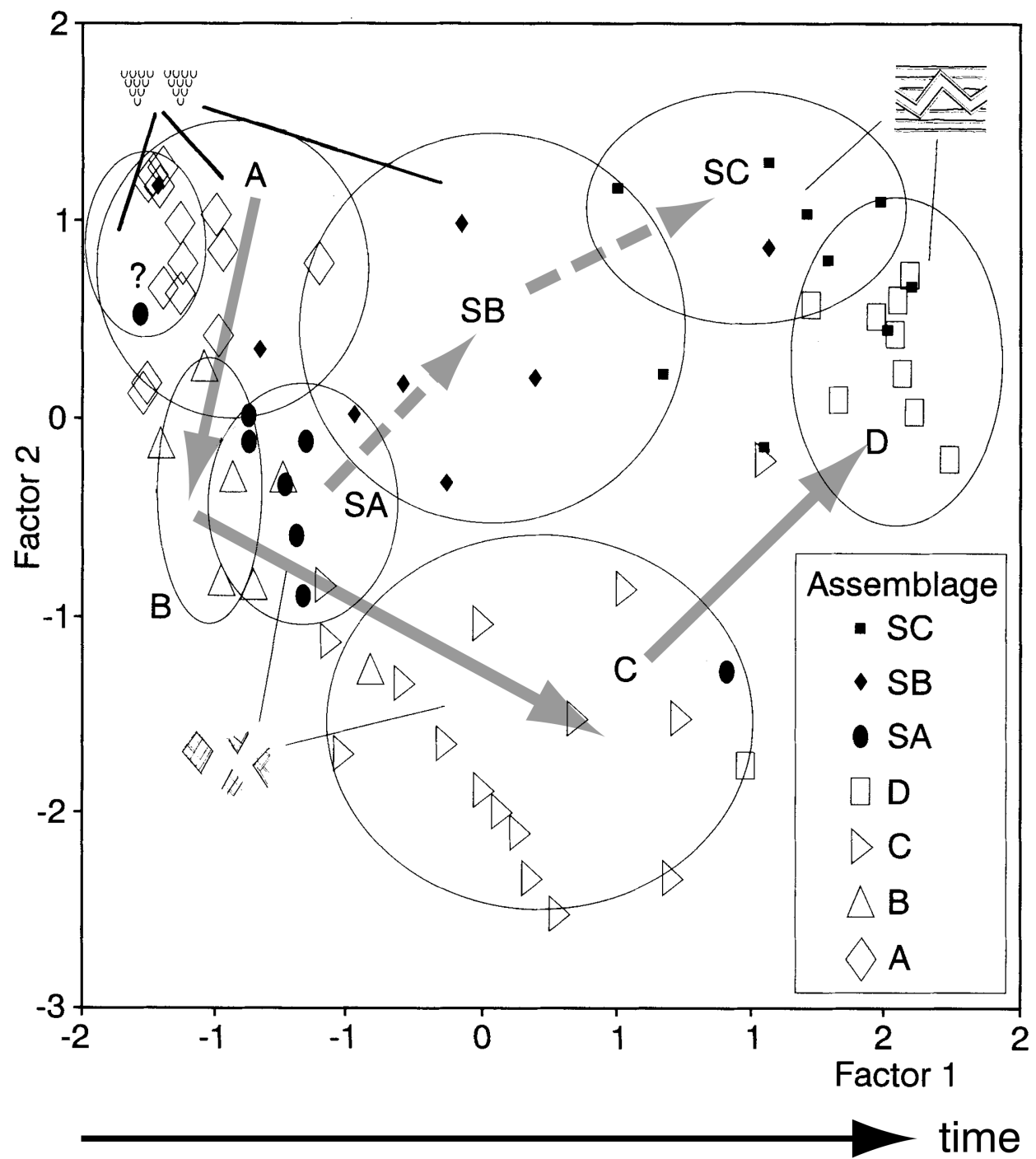

Figure 9 Globular Amphorae ceramics. Correspondence analyses of decoration patterns from domestic sites (SA, $\mathrm{SB}, \mathrm{SC})$ and burials (A, B, C, D).

- the ornamental differences in the decoration of domestic sites, collective burials, and single graves around $3000 \mathrm{cal} \mathrm{BC} \mathrm{(Figure} \mathrm{12),} \mathrm{which} \mathrm{display} \mathrm{the} \mathrm{association} \mathrm{of} \mathrm{different} \mathrm{sign} \mathrm{systems}$ with differences in the function of site types;

- the change of deposition rate and deposition context of both ground stone axes (Figure 13) as well as copper artifacts in time, which can be associated with changing production and importance through the Late Neolithic centuries.

Until combined $\mathrm{CA}$ and ${ }^{14} \mathrm{C}$ analyses were used, the discussion of these topics was possible only with uncertainties. A typological discussion masked independent inquiries in the chronological development: the circle "style $=$ chronological phase" did not allow proper interpretation of the social meanings of material culture. 


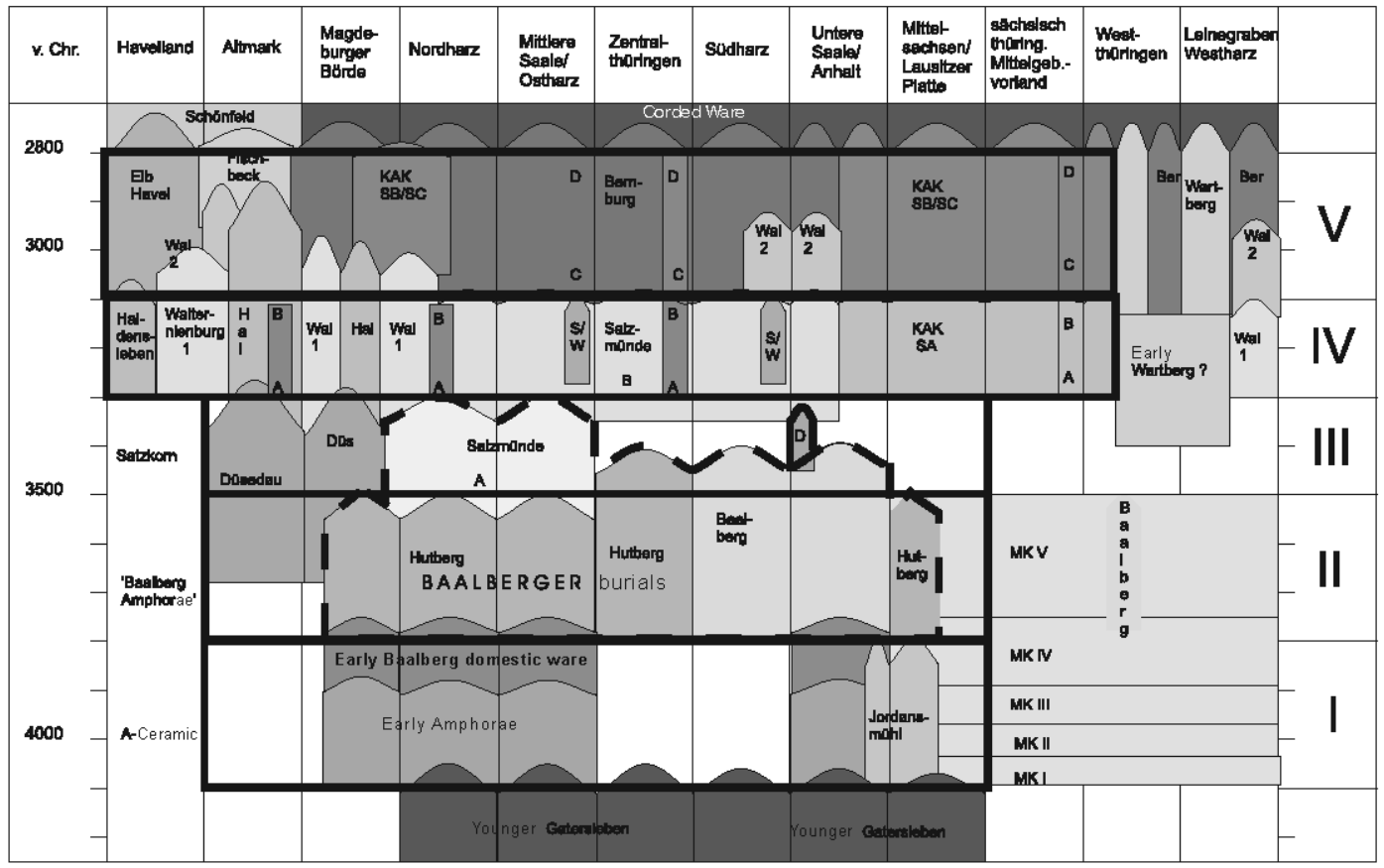

Figure 10 Chronological model of the Neolithic development in the Mittelelbe-Saale region 4100-2800 cal BC

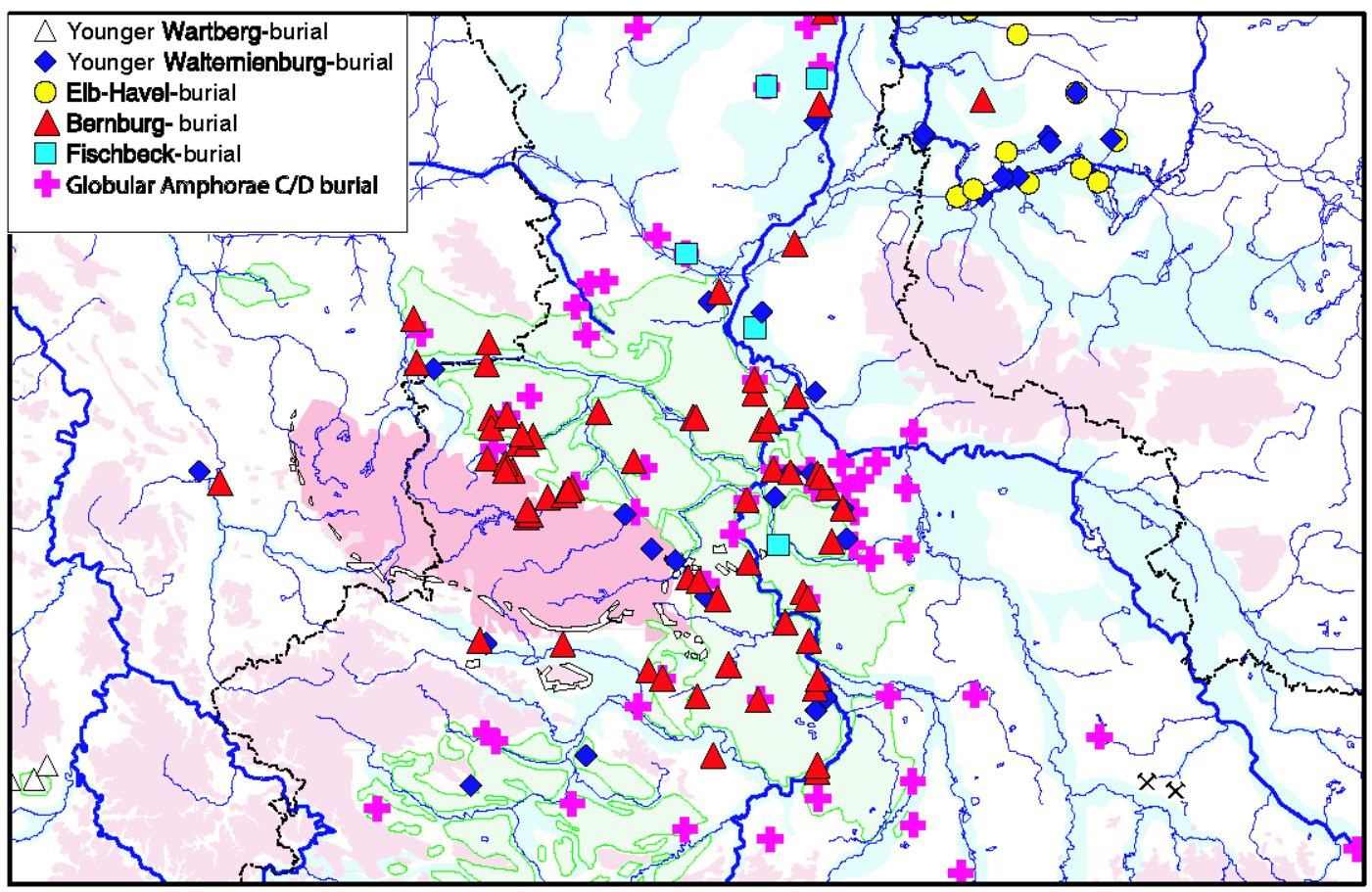

Figure 11 The interwoven spatial distribution of different ceramic styles around $3000 \mathrm{cal} \mathrm{BC}$ in central Germany (burial sites) 


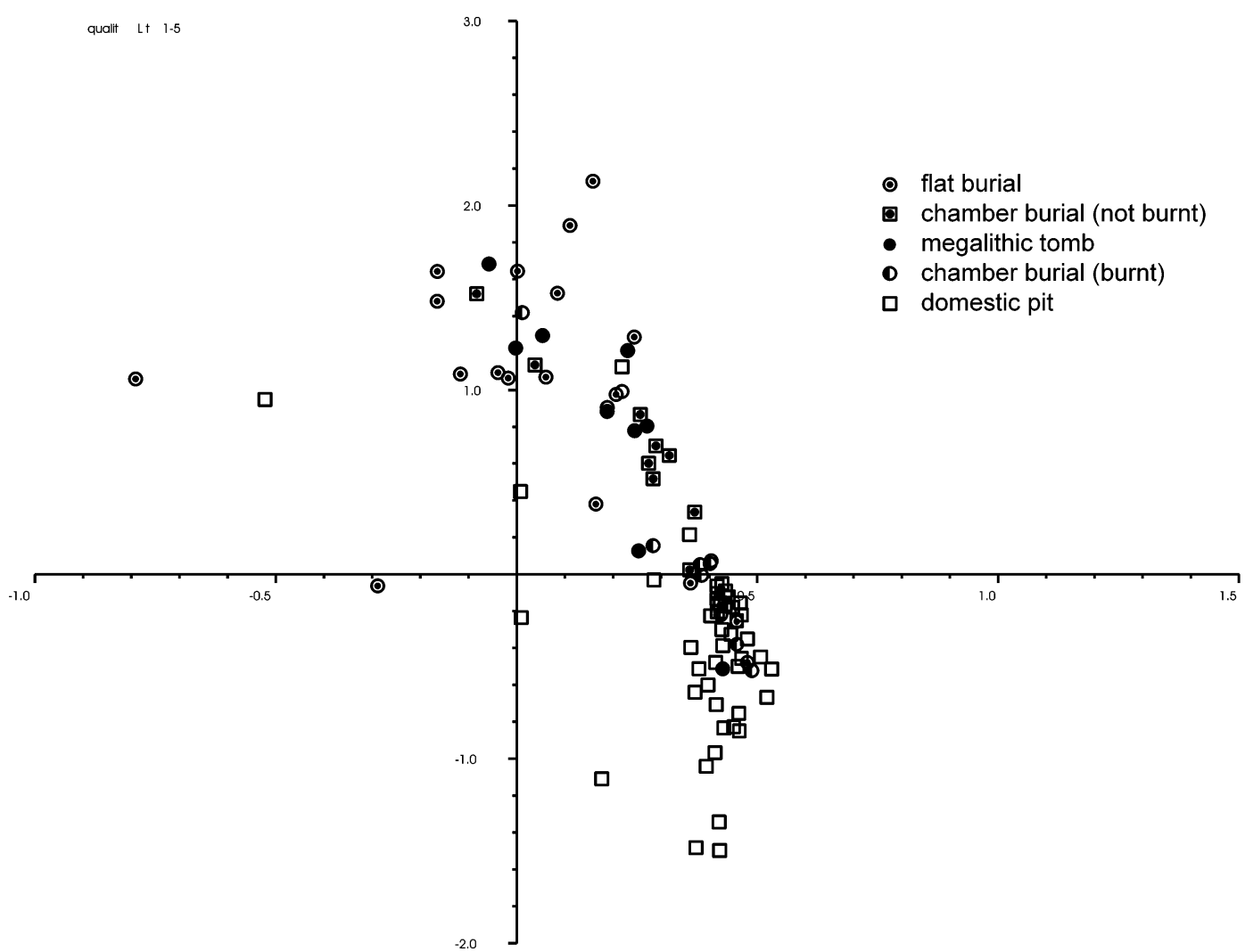

Figure 12 Correspondence analysis of contemporary ornament differences in the decoration of Late Neolithic assemblages in the Mittelelbe-Saale region. The 2. Eigenvector reflects differences of domestic sites, collective burials, and single graves around $3000 \mathrm{cal} \mathrm{BC}$.

The deconstruction of pure stylistic "chronologies" in central Germany led to a chronological model, which aided the reconstruction and discussion of depositional processes, social questions, and technological developments.

\section{CONCLUSION}

The methodological necessity of the independence of different analytical stages demonstrates a new potential of scientific dating methods in combination with statistical analyses of material culture. While correspondence analysis (CA) is a powerful tool in the detection of assemblage groups of similarities in material culture (here: styles), ${ }^{14} \mathrm{C}$ data are useful in identifying CA gradients as chronologically relevant or even not relevant. As a result, this approach was able to deconstruct the idea of a linear stylistic development in Neolithic ceramic groups of central Germany, and construct a model of multicultural use of styles by these Neolithic societies. There is the chance now to take advantage of the archaeological record for the reconstruction of social meaning. A further step might be the development of CA programs that integrate the information from scientific dating methods, allowing the detection of the rate of innovation. 

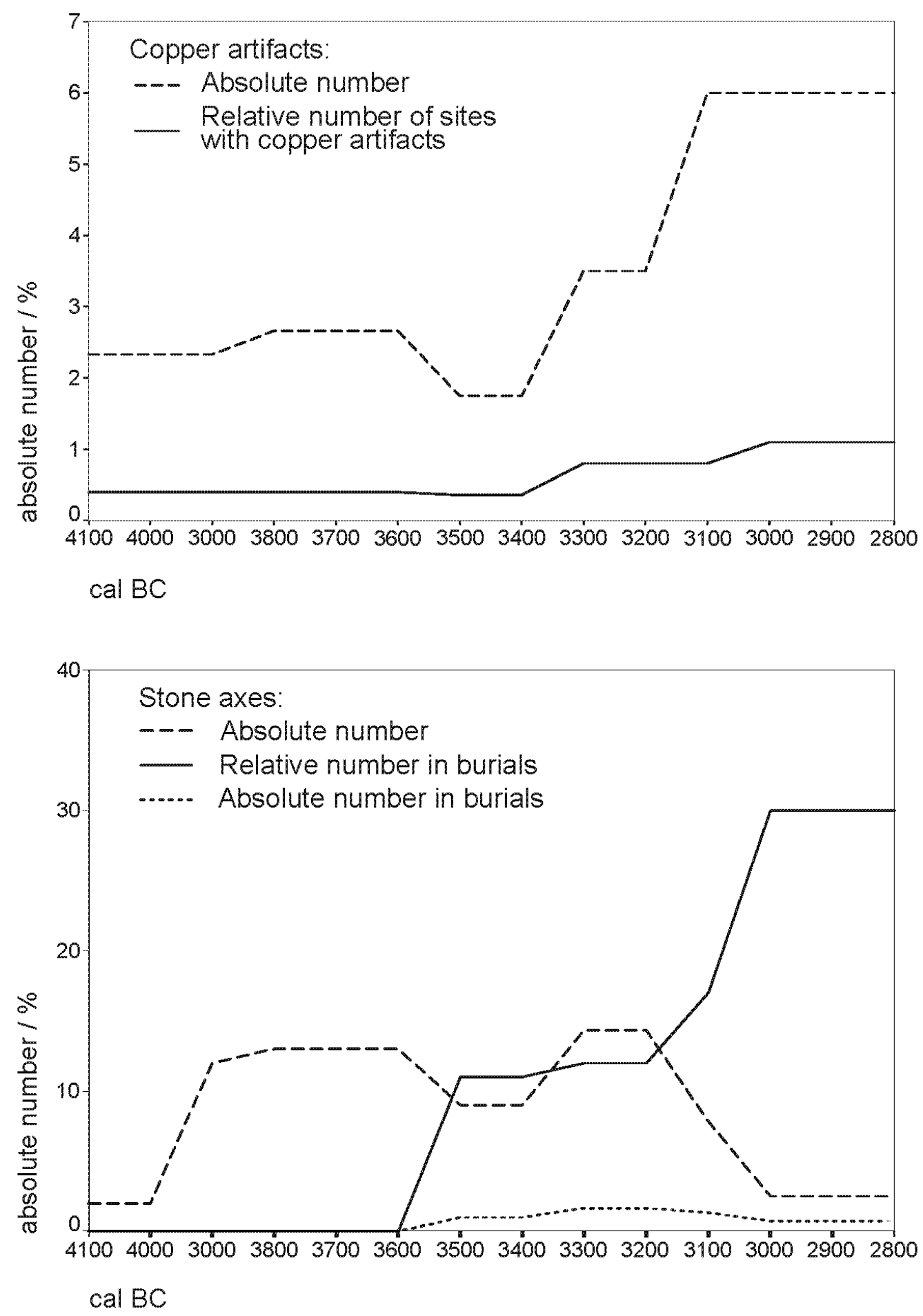

Figure 13 The quantitative change in deposition rate and deposition context of ground stone axes (bottom) and copper artifacts (top) in central Germany, 4100-2800 cal BC per 100-yr intervals. 


\section{ACKNOWLEDGMENTS}

The outlined results were conducted in different projects, financed by the German Research Foundation (DFG): Mu-1259/3. Discussions with Marie Nadeau from the Leibniz Laboratory Kiel and Mara Weinelt from the Graduate School "Human Development in Landscapes" helped in many respects. Holger Dieterich from the Institute of Pre- and Protohistoric Archaeology Kiel has redone some figures.

\section{REFERENCES}

Bayliss A, Bronk Ramsey C, van der Plicht J, Whittle A. 2007. Bradshaws and Bayes: towards a timetable for the Neolithic. Cambridge Archaeological Journal 17(Supplement S1):1-28.

Beran J. 2000a. Der mitteldeutsche Raum als Grenzland vorgeschichtlicher Kulturkreise im Jung- und Endneolithikum. In: Beier H-J, Einicke R, editors. Varia Neolithica I. Langenweissbach: Beier und Beran. p 131-2.

Beran J. 2000b. Zitate und Thesen zum archäologischen Nachweis von Stammesgebieten. In: Beier H-J, Einicke R, editors. Varia Neolithica I. Langenweissbach: Beier und Beran. p 25-31.

Czebreszuk J, Müller J, editors. 2001. Die absolute Chronologie in Mitteleuropa 3000-2000 v. Chr. Studien zur Archäologie in Ostmitteleuropa 1. Rahden: Verlag Marie Leidorf GmbH.

Furholt M. 2003. Die absolutchronologische Datierung der Schnurkeramik in Mitteleuropa und Südskandinavien. Universitätsforschungen zur Prähistorischen Archäologie 101. Bonn: Dr. Rudolf Habelt GmbH.

Greenacre MJ. 2007. Correspondence Analysis in Practice. 2nd edition. Boca Raton, FL, USA: Chapman \& Hall/CRC. 280 p.

Hafner A, Suter PJ. 1997. Entwurf eines neuen Chronologie- Schemas zum Neolithikum des schweizerischen Mittellandes. Archäologisches Korrespondenzblatt 27:549-65.

Lichardus J. 1976. Rössen-Gatersleben-Baalberge. Saarbrücker Beiträge zur Altertumskunde. Bonn: Habelt. $320 \mathrm{p}$.

Müller J. 1996. The use of correspondence analysis for different kinds of data categories: domestic and ritual Globular Amphorae sites in Central Germany. Analecta Praehistorica Leidensia 28:217-22.
Müller J. 2000. Radiokarbonchronologie-Keramiktechnologie-Osteologie-Anthropologie-Raumanalysen. Beiträge zum Neolithikum und zur Frühbronzezeit im Mittel-Elbe- Saale-Gebiet. Bericht der Römisch-Germanischen Kommission 80. p 25-211.

Müller J. 2001. Soziochronologische Studien zum JungSpätneolithikum im Mittelelbe-Saale-Gebiet (41002700 v. Chr.). Eine sozialhistorische Interpretation prähistorischer Quellen. Vorgeschichtliche Forschungen 21. Rahden: Westfalen.

Müller J, van Willigen J. 2001. New radiocarbon evidence for European Bell Beakers and the consequences for the diffusion of the Bell Beaker phenomenon. In: Nicolis F, editor. Bell Beakers Today. Trento. p 59-80.

Müller-Scheessel N, Burmeister S. 2006. Einführung: Die Identifizierung sozialer Gruppen. Die Erkenntnismöglichkeiten der Prähistorischen Archäologie auf dem Prüfstand. In: Burmeister S, Müller-Scheessel N, editors. Soziale Gruppen - kulturelle Grenzen. Die Interpretation sozialer Grenzen in der Prähistorischen Archäologie. p 9-38.

Raetzel-Fabian D, Furholt M. 2006. Frühbadener Elemente im Neolithikum Mitteldeutschlands: "Die Schöninger Gruppe." Archäologisches Korrespondenzblatt 36:347-58.

Tilley CY, editor. 1990. Reading Material Culture: Structuralism, Hermeneutics, and Post-Structuralism. Chichester: Wiley-Blackwell. 372 p.

Tilley CY. 1996. An Ethnography of the Neolithic: Early Prehistoric Societies in Southern Scandinavia. New York: Cambridge University Press.

Wotzka H-P. 2000. "Kultur" in der deutschsprachigen Urgeschichtsforschung. In: Fröhlich S, editor. Kolloquium zum Kulturbegriff Halle. Saale. p 55-80. 


\section{APPENDIX 1: ${ }^{14} \mathrm{C}$ DATES OF BAALBERGE BURIALS (FROM MÜLLER 2001:83ff.) \\ Baalberge A}

Bahrendorf-Stemmern

GrN-23314: $4870 \pm 35$ BP, 3695 cal BC (68.2\%) $3640 \mathrm{cal} \mathrm{BC}$, human bone, Burial 13.

KIA-3104: $4640 \pm 30$ BP, 3500 cal BC (46.8\%) 3450/3380 cal BC (21.4\%) 3350 cal BC, human bone, Burial 15.

\section{Köthen-Lohmannstr}

GrN-23309: $4850 \pm 30$ BP, 3700 cal BC (61.6\%) 3630 cal BC/3560 cal BC (6.6\%) 3540 cal BC, human bone, Burial 2.

\section{Kroppenstedt-Kalkberg}

KN-4864: $4564 \pm 60 \mathrm{BP}, 3370$ cal BC (24.8\%) 3290 cal BC/3240 cal BC (43.4\%) 3100 cal BC, human bone, single burial.

\section{Baalberge B}

Alsleben

Bln-3690: $4790 \pm 90$ BP, 3660 cal BC (56.0\%) 3500/3430 cal BC (12.2\%) 3370 cal BC, animal bone, ritual pit (Stelle 2, T. $0.90 \mathrm{~m}$ ).

Bahrendorf-Stemmern

KIA-3103: $4700 \pm 40$ BP, 3620 cal BC (6.3\%) 3590/3520 cal BC (10.3\%) 3490/3470 cal BC (51.6\%) 3370 cal BC, human bone, Burial 22.

Cörmigk-Sixdorf

$\mathrm{KN}-4863: 4640 \pm 52 \mathrm{BP}, 3510 \mathrm{cal} \mathrm{BC}(49.6 \%) 3410 / 3390 \mathrm{cal} \mathrm{BC}(18.6 \%) 3340 \mathrm{cal} \mathrm{BC}$, human bone, Burial 40.

Groß Wirschleben-Galgenhügel

Hd-18799: $4771 \pm 32$ BP, 3640 cal BC (13.1\%) 3610/3600 cal BC (55.1\%) 3510 cal BC, human bone, single burial.

Köthen-Lohmannstr

GrN-23310: $4790 \pm 35$ BP, 3640 cal BC (15.8\%) 3610/3590 cal BC (52.4\%) 3520 cal BC, human bone, Burial 6.

Preußlitz-Ilgensteinscher Mühlenberg

KIA-3109: $4750 \pm 30$ BP, 3630 cal BC (37.4\%) 3570/3540 cal BC (20.3\%) 3500/3410 cal BC (10.5\%) 3380 cal BC, human bone, Burial 6.

Quenstedt-Schalkenburg

Bln-2005: $4710 \pm 40$ BP, 3620 cal BC (11.6\%) 3590/3530 cal BC (12.2\%) 3490/3460 cal BC (44.4\%) 3370 cal BC, human bone, Burial 1.

Further dates, of which the assemblages are typologically in general Baalberge, are listed in Müller (2001:83ff.) 


\section{APPENDIX 2: ${ }^{14} \mathrm{C}$ DATES OF SALZMÜNDE ASSEMBLAGES (FROM MÜLLER 2001:116ff.)}

\section{Erfurt-Gispersleben}

Bln-3915: $4590 \pm 70$ BP, 3500 cal BC (11.4\%) 3450/3380 cal BC (24.7\%) 3290/3240 cal BC (32.1\%) 3100 cal BC, animal bone, pit 37.

Bln-3949: $4690 \pm 50$ BP, 3620 cal BC (4.7\%) 3600/3520 cal BC (63.5\%) 3370 cal BC, animal bone, pit 37. Bln-3950: $4480 \pm 80$ BP, 3340 cal BC (45.2\%) 3150/3140 cal BC (23.0\%) 3030 cal BC, animal bone, pit 37.

Helfta

Hd-19171: $4595 \pm 25$ BP, 3490 cal BC (6.9\%) 3470/3380 cal BC (61.3\%) 3330 cal BC, animal bone, pit 25.

\section{Köthen-Junkers Motorenfabrik}

Kn-4908: $4227 \pm 32$ BP; 2890 cal BC (18.5\%) 2860/2810 cal BC (35.5\%) 2760/2720 cal BC (14.2\%) 2700 cal BC, animal bone, pit 10 .

Kn-5012: $4110 \pm 39$ BP, 2870 cal BC (22.1\%) 2810/2700 cal BC (46.1\%) 2580 cal BC, animal bone, pit 10.

\section{Mücheln-Galgenhügel}

Kn-4905: $4162 \pm 54$ BP, 2880 cal BC (7.9\%) 2850/2830 cal BC (8.4\%) 2790/2780 cal BC (51.8\%) 2620 cal BC, animal bone, pit 3 .

Peißen-Am Mühlberg

KN-5014: $4363 \pm 43$ BP; 3040 cal BC (68.2\%) 2910 cal BC, animal bone, pit 73. Gd-10166: $4550 \pm 90$ BP; 3370 cal BC (68.2\%) 3090 cal BC, animal bone, pit 73 . KN-5016: $4412 \pm 48$ BP, 3100 cal BC (68.2\%) 2920 cal BC, animal bone, pit 76.

\section{Preußlitz-Plömnitz-Mäuseberg}

HD-18962: $4426 \pm 35$ BP, 3100 cal BC (38.6\%) 3020/2990 cal BC (29.6\%) 2920 cal BC, human bone, burial.

\section{Weißenfels-Eselsweg}

Bln-1353: $4586 \pm 60$ BP, 3520 cal BC (68.2\%) 3350 cal BC, human bone, ritual pit 27.

Bln-1354: $4665 \pm 60$ BP, 3520 cal BC $(68.2 \%) 3350$ cal BC, human bone, ritual pit 27.

Bln-1553: $4746 \pm 60$ BP, 3640 cal BC (51.3\%) 3500/3420 cal BC (16.9\%) 3370 cal BC, human bone, ritual pit 27.

\section{Wallendorf-Hutberg}

Kn-4899: $4813 \pm 61$ BP, 3660 cal BC (23.4\%) 3610/3600 cal BC (43.3\%) 3510/3400 cal BC (1.5\%) 3390 cal BC, animal bone, feature 49 .

KN-4902: $4841 \pm 58$ BP, 3700 cal BC (44.3\%) 3620/3580 cal BC (23.9\%) 3530 cal BC, animal bone, feature 136 .

KN-4909: $4661 \pm 44$ BP, 3510 cal BC (57.3\%) 3410/3390 cal BC (10.9\%) 3360 cal BC, animal bone, feature 138.

$\mathrm{KN}-4898: 4483 \pm 76 \mathrm{BP}, 3340 \mathrm{cal} \mathrm{BC}(47.3 \%) 3150 / 3140 \mathrm{cal} \mathrm{BC}(14.6 \%) 3080 \mathrm{cal} \mathrm{BC} / 3070 \mathrm{cal} \mathrm{BC}$ (6.3\%) $3030 \mathrm{cal} \mathrm{BC}$, animal bone: feature 131 .

KN-4900: $4458 \pm 45$ BP, 3310 cal BC (24.1\%) 3230/3190 cal BC (5.4\%) 3160/3120 cal BC (29.6\%) 3030/ $2980 \mathrm{cal} \mathrm{BC}(9.2 \%) 2930 \mathrm{cal} \mathrm{BC}$, animal bone, feature 103.

Kn-4901: $4170 \pm 45$ BP, 2880 cal BC (7.1\%) 2850/2820 cal BC (8.1\%) 2790/2780 cal BC (49.3\%) 2660/ $2640 \mathrm{cal} \mathrm{BC}(3.7 \%) 2620 \mathrm{cal} \mathrm{BC}$, animal bone, feature 44. 